\title{
Review
}

\section{Crop-to-wild gene flow, introgression and possible fitness effects of transgenes}

\author{
Eric JENCZEWSKI ${ }^{1, *}$, Joëlle RONFORT ${ }^{2}$ and Anne-Marie CHĖVRE ${ }^{1}$ \\ ${ }^{1}$ Unité Mixte de Recherche ENSAR-INRA, Amélioration des plantes et biotechnologies végétales - Domaine de la Motte, BP 35327 , \\ 35653 Le Rheu Cedex, France \\ ${ }^{2}$ UFR-GAP INRA Montpellier, Domaine de Melgueil, 34130 Mauguio, France
}

Crop-to-wild gene flow has received close attention over the past ten years in connection with the development and cultivation of transgenic crops. In this paper, we review key examples of crop/wild sympatry and overlapping flowering phenology, pollen and seed dispersal, the barriers to hybridisation and introgression, the evolution and fate of interspecific hybrids, their fitness, and the potential cost of transgenes. We pay particular attention to ways in which the evolution and divergence between crops and their wild relatives may interfere with these successive steps. Our review suggests that crop-to-weed gene flow is highly idiosyncratic and that crop gene dispersion will certainly be very difficult to preclude totally. Future directions for research should thus focus on the long-term establishment and effects of transgenes on natural communities.

Keywords: gene flow / hybridization / introgression / hybrid fitness / transgene cost / crop-wild complexes

\section{INTRODUCTION}

Gene exchange has always been a major determinant of the evolution in crop-weed-wild complexes, i.e. groups of crops, accompanying weeds and wild species that exchange genes. On the one hand, many crops have evolved through recurrent cycles of hybridization/ differentiation from their wild/weedy relatives (Harlan, 1992). Wild species are still used in plant breeding as a rich source of genes that may be transferred into crop germplasm in order to expand its genetic basis, to confer resistance or increase tolerance to biotic and abiotic stresses, or to transfer new agronomic features into the cultivated forms (Frankel et al., 1995). On the other hand, natural crop-to-wild hybridisation has sometimes led to the extinction of crop relatives or has generated new races of weeds that are more aggressive and better adapted to man-made habitats (Ellstrand et al., 1999). Despite its obvious evolutionary significance, crop-to-weed gene flow has received little experimental attention.

The prospect of commercial release of genetically engineered plants has begun to reverse this trend. A large literature is now dedicated to the assessment of transgene escape through pollen and seeds, and its potential ecological and agricultural effects (Snow and Morán Palma, 1997). The main concern is that widespread cultivation of some transgenic crops could accelerate the evolution of undesirable and more invasive weeds, thereby leading to the erosion of biodiversity or to ecosystem disequilibrium effects (Tiedje et al., 1989; Snow and Morán Palma, 1997). Although this threat applies to traditionally bred crops (Ellstrand et al., 1999), differences between genetic engineering and traditional breeding regarding the nature, number, and effects of the introduced traits may make some types of GMOs (Genetically Modified Organisms) more risky than traditional crops (Regal, 1994). Other potential problems due to the cultivation of GMOs have been identified. Crop-to-crop gene flow may lead to gene stacking (Ellstrand, 2001), crop product pollution (while crop diversification is ongoing), the rapid modification of pest communities and selection of more aggressive

\footnotetext{
* Corresponding author:
}

Tel.: 0033 (0)2 234851 31; fax: 0033 (0)2 234851 20; e-mail: jenczews@ rennes.inra.fr 


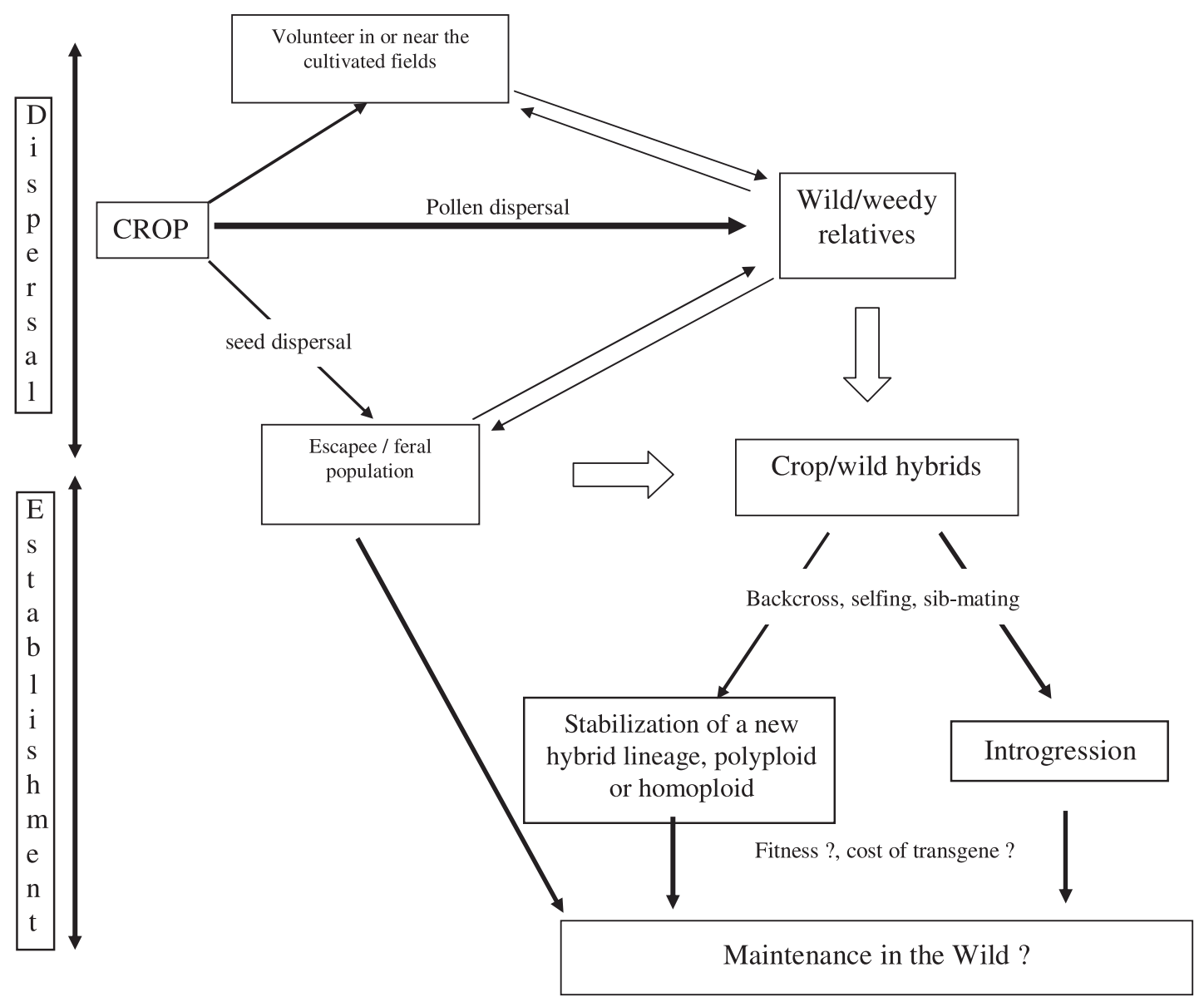

Figure 1. Schematic representation of the main steps for crop-to-wild gene flow.

pathogens, and unintended effects on non-target organisms (Poppy, 2000). Notwithstanding their importance, we will not address these questions in this paper, but focus on the issues related to crop-to-wild gene flow.

Effective crop-to-wild gene flow depends on the completion of a number of successive steps required for gene dispersal (Fig. 1): (i) the presence of crops and close relatives growing nearby, (ii) their biology and phenology in relation to pollen and seed dispersal, (iii) the production of viable and fertile F1 hybrids, (iv) the production of fertile successive generations, (v) the opportunity for gene transmission, chromosome recombination and crop gene introgression into the wild genetic background, and ultimately (vi) the persistence of introgressed crop genes in natural communities. In this paper, we will examine key examples for each of these, and point out how the evolution of both crops and their wild relatives affects the potential for crop-wild hybridization and introgression.

\section{(TRANS)GENE DISPERSAL}

\section{Spatial gene dispersal via pollen: the role of the cultivated "source" and natural "sink" populations}

Crop-to-wild gene flow has long been considered to be mostly pollen mediated (Ellstrand and Hoffman, 1990). Gene dispersal through pollen requires the presence of sexually compatible relatives in the regions where a crop is commonly grown. On a large spatial scale, the probability of crop gene flow depends on the geographic distributions of crops and their wild relatives; such contacts are generally more frequent in the crop's centers of origin and/or centers of diversity (Simmonds, 1995). 
Review: Crop-to-wild gene flow, introgression and fitness effects of transgenes

On a smaller spatial scale, crop gene dispersal is expected to be stronger into its more common weedy relatives, because there will be closer and more numerous zones of co-occurrence. These species are also to be considered as the most risky potential recipients for transgenes because they are already adapted to man-made habitats and can be difficult to control.

Several authors have listed the major crops and their co-occurring wild relatives in the following western countries: the Netherlands (De Vries et al., 1992), UK (Raybould and Gray, 1993), USA (Snow and Morán Palma, 1997), Austria (Pascher and Gollmann, 1997). These surveys are important to identify the most likely wild partner(s) for crop-to-wild gene flow and set up research priorities. However, even if broad information on the distribution and importance of wild species is available, little is known about the precise extent of their proximity to related crops. Remote sensing has recently been used to address this problem. For example, satellite imagery proved to be an efficient method for identifying all the possible contact zones between Brassica napus and weedy B. rapa across south-east England (Wilkinson et al., 2000).

The potential for spontaneous crop-to-wild gene flow is then determined by the extent to which flowering period overlaps and by pollen dispersion. Experimental data on comparative crop/wild phenology are scarce, but suggest that wild populations usually display a wider range of flowering dates than crops. This difference in the length of flowering makes the overlap more likely, because at least some wild plants will flower in synchrony with most of the cultivated ones. Conversely, overlaps can be limited, so that many wild plants will be isolated from the cultivated pollen source (Renno and Winkel, 1996). Growing early or late cultivars may thus have significant effects on the extent of crop gene dispersal.

As regards crop pollen dispersal, most studies have described highly leptokurtic distributions, with most pollen grains moving over very short distances, and then more scarcely over longer distance. These observations apply to both wind- and insect-pollinated species: turnip (Manasse, 1992), cotton (Karieva et al., 1994), potato (Tynan et al., 1990; McPartlan and Dale, 1994; Skogsmyr, 1994; Conner and Dale, 1996), oilseed rape (Scheffler et al., 1993; Morris et al., 1994; Lavigne et al., 1998), radish (Klinger et al., 1992), ryegrass (Giddings et al., 1997a), sunflower (Arias and Rieseberg, 1994), meadow fescue (Rognli et al., 2000), and alfalfa (St Amand et al., 2000). Although long-range pollen movement is a low probability event (Karieva et al.,
1994), hybridization between crops and weed/wild relatives have also been frequently reported up to hundreds of meters away from the cultivated source (Kirkpatrick and Wilson, 1988; Klinger et al., 1992; Arias and Rieseberg, 1994; Arriola and Ellstrand, 1996). Low-frequency long-distance dispersal is highly relevant for risk assessment, since a small number of successful migrants per generation is sufficient to modify the structure of recipient populations.

Generalizations about the expected distribution of hybridization events are not straightforward. Many studies have demonstrated considerable, and almost unpredictable, variations of crop-to-weed gene flow between discontinuous patches of plants (Raybould and Gray, 1993; Morris et al., 1994; Giddings et al., 1997b). These variations are not always related to interpatch distance (Manasse, 1992) and depend on many extrinsic factors (Raybould and Gray, 1993; Giddings et al., 1997b). Notably, the shape, relative size and density of both the crop "donor" and "recipient" wild/weedy populations prove to be important (Jorgensen and Andersen, 1994; Chèvre et al., 2000). For instance, Ellstrand et al. (1989) found essentially no gene exchange among three small populations of insectpollinated wild radish a few thousand meters apart, but substantial gene flow into them from very large populations thousands of meters away (see also Klinger et al., 1992). Such asymmetric gene flow from cultivated fields into wild/weedy populations is expected when the relative size of the recipient wild/weedy populations is small (Ellstrand, 1992; Ellstrand et al., 1999) or when they are more fragmented.

Modelling pollen dispersal offers a potential solution to address these problems, provided that the pollen distribution of each individual plant is adequately known (Lavigne et al., 1998). This approach requires (i) developing robust estimators of individual pollen dispersal functions (which fit experimental data) and (ii) using these functions to achieve quantitative predictions for pollen dispersion in various agricultural designs.

Finally, it must be acknowledged that crop gene dispersal does not necessarily imply that gene flow occurs only in one direction, from crops into their wild relatives. Using cytoplasmic DNA markers, Boudry et al. (1993) demonstrated that weed beets arise from the accidental pollination of cultivated sugar beets (Beta vulgaris ssp. vulgaris) by adventitious wild beets (B. vulgaris ssp. maritima) in seed production areas. Such wild-to-crop gene flow can be expected when crop seeds are able to disperse and establish feral populations. 


\section{Spatial and temporal (trans)gene dispersal via seeds and vegetative propagules}

Two different situations should be considered when assessing crop gene dispersal via seeds or vegetative propagules. First, dispersal may occur in space, due to the movement of seeds or vegetative propagules from cultivated fields into natural communities. This first route may result in the formation of feral populations when escaped crop plants are able to survive in the absence of human care (e.g. forage crops). Second, dispersion may occur in time due to delayed hybridization between wild and cultivated plants that have moved into natural communities (Linder and Schmitt, 1994; 1995) or persisted after harvesting.

Little is known about the extent of spatial seed dispersal (Crawley and Brown, 1995) or the potential persistence of feral populations (Crawley et al., 1993; Pessel et al., 2001). Spatial seed dispersal by natural means is often considered to be low because most crops have lost their ability for independent seed dispersal (De Wet and Harlan, 1975). Athough substantial dispersion can be mediated by seed spillage during harvest (Price et al., 1996) or transport (Crawley and Brown, 1995) resulting in dispersal over very long distances, crop seed dispersal is expected to be over shorter distances than pollen. The potential for temporal dispersal of transgenes primarily depends upon the initial level of crop seed dormancy, the longevity of seeds in the soil, and the germination behavior of seeds in response to environmental cues (Linder and Schmitt, 1994). Although most crops lack extensive seed dormancy and longevity (Lewis, 1973; Hails et al., 1997; Chadoeuf et al., 1998), some of them, such as oilseed rape, retain sufficient dormancy and longevity to persist as volunteers during crop rotation, notably when huge amounts of seeds are lost at harvest. Feral populations of oilseed rape have persisted along roadsides for 3-4 years after dispersal (Crawley and Brown, 1995) or even longer (Pessel et al., 2001). The dynamics of these feral populations in natural or semi-natural habitats is complex. Their persistence may be longer if transgene(s) increase the fitness of the escaped plants (Stewart et al., 1997).

Rare establishment of crop individuals via seeds or vegetative propagules can provide repeated opportunities for the production of advanced generations of hybrids, and increase the likelihood of introgression over evolutionary time (e.g. Hodges et al., 1996). Crop seed dispersal can therefore be an important step for further gene flow between wild and cultivated populations. This contention calls for a better characterisation of spatial and temporal crop seed dispersal and persistence.

\section{The production of F1 hybrids between crops and their wild relatives: insights into the nature and strength of reproductive barriers}

The degree of cross-compatibility between cultivated plants and their wild relatives has received close attention (Tab. 1), primarily because crosses between crops and related species have been extensively used in plant breeding. More recently, the chance for reciprocal cropto-wild hybridization has been evaluated for a large number of crops and their wild relatives: for example, Beta (Santoni and Bervillé, 1992; Boudry et al., 1993), Brassica (Chèvre et al., 1998a), Chenopodium (Wilson and Manhart, 1993), Cucurbita (Kirkpatrick and Wilson, 1988; Wilson, 1990), Helianthus (Arias and Rieseberg, 1994; Whitton et al., 1997), Medicago (Jenczewski et al., 1999), Oryza (Langevin et al., 1990), Pennisetum (Robert et al., 1991), Raphanus (Klinger et al., 1992), Setaria (Till-Bottraud et al., 1992), Sorghum (Arriola and Ellstrand, 1996), Triticum (Seefeldt et al., 1998; Zemettra et al., 1998), and Zea (Doebley, 1990). These data indicate that crops are usually cross-compatible with their direct progenitors, and that the chance for crop-wild hybridization decreases with increasing genetic and phenotypic divergence (Tab. 1); a few intergeneric hybrids were also reported between some crops and wild related species (Tab. 1). In some instances, the level of crop-wild compatibility is genotypically determined (Baranger et al., 1995; Sacks et al., 1997), and under a simple genetic control. For example, a single locus restricts crossability between teosinte and maize (Evans and Kermicle, 2001).

Evidence that hybridization occurs between a large number of crops and their wild relatives suggests that most of the reproductive barriers that have accompanied the process of plant domestication (Harlan, 1992; van Raamsdonk, 1995) are imperfect. Domestication is a very recent process on the evolutionary scale; most crops and their progenitors have diverged for less than 12000 years (Simmonds, 1995), which is not sufficient to establish impermeable reproductive barriers. For instance, neither mating systems nor polyploidy, which have been viewed as the most efficient mechanisms by which crops and their wild relatives can become reproductively isolated, ensure complete reproductive isolation.

Although most cases of crop-wild hybridisation are observed between outcrossing species (Kirkpatrick and Wilson, 1988; Doebley, 1990; Wilson, 1990; Klinger 
Review: Crop-to-wild gene flow, introgression and fitness effects of transgenes

Table 1. Examples of the degree of cross-compatibility between crops and their wild relatives (data compiled from Gallais and Bannerot, 1992).

For each cultivated species, the status of the ancestral species is first indicated (same species/sub-species/related species).

\begin{tabular}{|c|c|c|c|c|c|c|c|c|}
\hline \multirow[b]{2}{*}{ Cultivated species } & \multicolumn{5}{|c|}{ Ancestral taxa } & \multicolumn{3}{|c|}{ Other related taxa } \\
\hline & Autogamous & Polyploid & $\begin{array}{c}\text { Same } \\
\text { species }\end{array}$ & Sub-species & $\begin{array}{c}\text { Related } \\
\text { species }\end{array}$ & Sub-species & Related species & Other genera \\
\hline $\begin{array}{l}\text { Triticum turgidum durum } \\
\text { (durum wheat) }\end{array}$ & yes & yes & ++ & & & $+[1]$ & $+[1]$ & $+1-$ \\
\hline $\begin{array}{l}\text { Triticum aestivum } \\
\text { (bread wheat) }\end{array}$ & yes & yes & ++ & & & $+[1]$ & $+{ }^{[1]}$ & $+/-$ \\
\hline $\begin{array}{l}\text { Brassica napus } \\
\text { (oilseed rape) }\end{array}$ & mixed & yes & $?$ & $?$ & $?$ & l & $+{ }^{[1]}$ & $?$ \\
\hline $\begin{array}{l}\text { Glycine max } \\
\text { (soybean) }\end{array}$ & yes & no & & & $\begin{array}{l}++ \\
\text { Glycine soja }\end{array}$ & l & - & $?$ \\
\hline $\begin{array}{l}\text { Hordeum vulgare } \\
\text { (barley) }\end{array}$ & yes & no & & & $\begin{array}{c}++ \\
(\text { H. sponta- } \\
\text { neum })\end{array}$ & I & + & $?$ \\
\hline Oryza sativa L. (rice) & yes & no & ++ & & & ++ & + & $?$ \\
\hline Pisum sativum (pea) & yes & no & & ++ & & I & ++ & - \\
\hline $\begin{array}{l}\text { Lupinus albus } \\
\text { (white lupin) }\end{array}$ & yes & no & & $\begin{array}{c}\quad++ \\
\text { L. a. ssp. } \\
\text { graecus }\end{array}$ & & & & \\
\hline $\begin{array}{l}\text { Lycopersicum esculentum } \\
\text { (tomato) }\end{array}$ & yes & no & ++ & & & l & + & - \\
\hline Phaseolus vulgaris (bean) & yes & no & ++ & & & l & + & - \\
\hline $\begin{array}{l}\text { Dactylis glomerata } \\
\text { (dactyl) }\end{array}$ & no & yes & ++ & & & ++ & ++ & $?$ \\
\hline $\begin{array}{l}\text { Festuca arundinacea } \\
\text { (fescue) }\end{array}$ & no & yes & ++ & & & ++ & + & - \\
\hline $\begin{array}{l}\text { Lolium perenne } \\
\text { (ryegrass) }\end{array}$ & no & yes & ++ & & & l & + & - \\
\hline Medicago sativa (alfalfa) & no & yes & ++ & & & ++ & $\stackrel{+}{+}$ & \\
\hline Zea mais (maize) & no & no & & $\begin{array}{c}++ \\
\text { Z.m. ssp. } \\
\text { parviglumis }\end{array}$ & & ++ & ++ & $\begin{array}{c}+ \\
\text { (Tripsacum sp.) }\end{array}$ \\
\hline $\begin{array}{l}\text { Helianthus anпuиs } \\
\text { (sunflower) }\end{array}$ & no & no & ++ & & & I & ++ & $?$ \\
\hline Beta vulgaris (beet) & no & no & & $\begin{array}{c}++ \\
\text { B.v. ssp. } \\
\text { maritima }\end{array}$ & & l & $\begin{array}{c}+_{[2]}^{[2]} \\
(\text { sect. Vulgares })\end{array}$ & - \\
\hline Trifolium pratense (clover) & no & no & ++ & & & l & $+[2]$ & \\
\hline $\begin{array}{l}\text { Capsicum аппиит } \\
\text { (pimento) }\end{array}$ & no & no & ++ & & & l & + & - \\
\hline $\begin{array}{l}\text { Brassica oleracea } \\
\text { (cabbage) }\end{array}$ & no & no & ++ & & & + & $\begin{array}{c}+ \text { (chromosome } \\
\text { doubling })\end{array}$ & - \\
\hline $\begin{array}{l}\text { Cynara scolymus } \mathrm{L} . \\
\text { (artichoke) }\end{array}$ & no & no & & & $\begin{array}{c}++ \\
(\text { Cynara } \\
\text { cardunculus })\end{array}$ & I & + & - \\
\hline
\end{tabular}

++: Complete crossability; +: crossability with some reduced fertility of the hybrids; -: crosses impossible without artificial manipulations.

[1] Crosses are reported with sp. or ssp. that share at least one set of homologous chromosomes with the cultivated species.

[2] Crosses are limited to species belonging to the same section as the cultivated species.

/ : No sub-species are known for the corresponding crops.

(?): Data not available. 
et al., 1992; Boudry et al., 1993; Arias and Rieseberg, 1994; Whitton et al., 1997; Jenczewski et al., 1999), preferential self-fertilization in the wild or cultivated populations does not totally preclude efficient dispersion of crop genes (Robert et al., 1991; Wilson and Manhart, 1993; Arriola and Ellstrand, 1996; Seefeldt et al., 1998; Zemetra et al., 1998). Self-fertilization is rarely absolute. Most autogamous species show outcrossing rates varying from $0.5 \%$ up to $5-7 \%$. Moreover, offspring between divergent autogamous species can demonstrate hybrid vigor that enhances the effective outcrossing rate of these species. Pollen competition can also account for the partial reproductive isolation between crops and relatives (Robert et al., 1991; Rieseberg et al., 1995) or change the frequency of interspecific hybridization. Hauser et al. (1997) showed that higher proportions of hybrid seeds were obtained on the diploid field mustard (B. rapa) and the allotetraploid oilseed rape (B. napus) when a mixture of pollen from the two species was applied.

Ploidy barriers in crop-wild complexes can arise when crops are domesticated after reaching a higher level of ploidy (e.g. Triticum aestivum, Solanum tuberosum, Coffea arabica, B. napus) and consequently these crop species lack wild relatives at the same level of ploidy. In other instances, diploid crops have polyploid relatives (e.g. Sorghum bicolor and S. halepense). In these complexes, the production of interspecific hybrids is reduced due to differences in ploidy levels between uniting gametes. However, interspecific hybrid production is possible and may be high when pollination occurs between an allopolyploid crop and one of its progenitors (Jorgensen and Andersen, 1994; Bing et al., 1996). Reciprocally, spontaneous hybridization between diploid S. bicolor and tetraploid S. halepense is frequent (Arriola and Ellstrand, 1996). Hybridization with less closely related species is also possible. It is generally more successful when the mother plant is the species with the higher ploidy level (Kerlan et al., 1992; Jorgensen and Andersen, 1994) because endosperm develops abnormally when the maternal:paternal genome ratio deviates from 2:1 (Johnston et al., 1980). The resulting triploid hybrids are not as systematically sterile as previously considered; some of them are able to produce euploid gametes and can thus serve as a bridges for gene flow or the formation of new polyploid species (Ramsey and Schemske, 1998). The production of unreduced gametes by the diploid parent can also contribute to the production of hybrids in the species with the highest ploidy level, since unreduced gametes restore the optimal 2:1 maternal:paternal genome ratio. The production of unreduced gametes is usually variable in populations and depends on genotype, environment, and their interactions (Bretagnolle and Thompson, 1995). It has been shown to occur at up to $30 \%$ per plant per generation in certain species, and can therefore contribute to significant interploid gene flow.

To conclude, a growing body of empirical data now demonstrates that crop-to-wild hybridization is likely when crops have sexually compatible relatives in adjacent ecosystems, although it often occurs at a very low frequency. Note that mating systems and differences in ploidy levels are not the only reproductive barriers that can limit crop-to-wild gene flow (see Arnold, 1997; Rieseberg, 1997; Rieseberg and Carney, 1998 for review). However, once gene dispersal has occurred, the question is then to understand whether genes will persist and establish in the natural populations of free-living relatives.

\section{(TRANS)GENE ESTABLISHMENT IN NATURAL POPULATIONS}

Until now, very few studies have attempted to measure directly the persistence of crop genetic markers in wild species after hybridization: e.g., raspberry (Luby and McNicol, 1995), sunflower (Whitton et al., 1997; Linder et al., 1998). For these two species, evidence of long-term introgression of crop genes into natural populations was reported (gene conferring spinelessness in raspberry, RAPD markers in sunflower). These direct measures of crop gene establishment raise questions about distinguishing introgressive markers from ones jointly inherited from a common ancestor. The same problem arises when population structure is used to infer past and present gene flow between crops and their relatives (Bartsch et al., 1999; Jenczewski et al., 1999). Most workers have thus concentrated on an alternative strategy that consists of analyzing the successive steps in the process of transgene establishment. Several determinants have been considered: (i) the genetic mechanisms that allow the transfer of cultivated genes into wild communities, (ii) the fitness of early hybrids relative to their parents, (iii) possible fitness costs or benefits that are associated with particular transgenes.

\section{Evolution and fate of interspecific hybrids: genetic mechanisms of introgression and speciation}

Introgression, the permanent incorporation of genes from one set of differentiated populations into another (Rieseberg and Wendel, 1993), is viewed as a common 
Review: Crop-to-wild gene flow, introgression and fitness effects of transgenes

outcome of hybridization. Although introgression between wild and domesticated plants is suspected to be widespread (De Wet and Harlan, 1975; Harlan, 1992; Rieseberg and Wendel, 1993; Ellstrand et al., 1999), it has rarely been demonstrated in wild populations (Luby and McNicol, 1995; Whitton et al., 1997; Linder et al., 1998). From a mechanistic standpoint, the extent of gene introgression depends on the interactions between recombination and selection.

At the whole genome scale, the probability for crop gene transfer depends on the level of genetic and structural homology between the genomes of crops and wild plants. More frequent introgression is expected when crops and their wild relatives share high levels of homology: e.g. Beta vulgaris $\times$ B. maritima (Boudry et al., 1993) or Raphanus sativus $\times R$. raphanistrum (Panetsos and Baker, 1967). Likewise, the extent of gene introgression from an allopolyploid crop to one of its relatives depends on the genome on which the gene is located; for instance, introgression of a transgene from oilseed rape (AACC) into field mustard (AA) is easier when the transgene is located on the A rather than the $\mathrm{C}$ genome of the crop (Mikkelsen et al., 1996; Metz et al., 1997; Tomiuk et al., 2000). When hybrids are formed between less related species, the chance for gene introgression varies with the genomic structure of the hybrids. Although most hybrids contain each parental genome at the haploid level, some of them can also contain one of the parental genome at the diploid level due to the production of unreduced gametes (Eber et al., 1998), or both parental genomes at the diploid level (Kerlan et al., 1992). These different structures provide different opportunities for chromosomes to pair and can promote or preclude introgression. Intergenomic pairing is also modulated by genes superimposed on genome differentiation. While the presence of such pairing regulators has been suspected in different allopolyploid crops (Riley, 1963; Gauthier and McGinnis, 1968; Jauhar, 1993), genes promoting or preventing pairing have also been characterised in wild species (Riley, 1963; Eber et al., 1994) in which they are usually polymorphic (Dvorak, 1972; Taylor and Evans, 1977). Depending on the alleles, the wild plants are able to induce a high, intermediate, or low amount of chromosome pairing in crop-wild hybrids, which directly influences the frequency of introgression.

Moreover, the probability for introgression is not only a characteristic of entire genomes, but also a property of individual genes or chromosomal segments (Harrison, 1990). First, crossing-overs are not randomly distributed along the physical length of the chromosomes, but occur more frequently in the distal rather than proximal regions of the chromosomes (Lukaszewski, 1995). It is not clear, however, if such a distribution is due to the chromosome segments themselves (recombination hotspots) or to their position relative to the telomeres. Second, the colinearity between homoeologous or orthologous chromosomes is rarely conserved along their whole lengths, but is usually restricted to chromosome segments (Truco et al., 1996; Moore et al., 1997). The physical distribution of these genetically related regions should play a significant role in driving the amount and distribution of introgressed alleles, since recombination seems to occur preferentially between the most homoeologous regions (Delourme et al., 1998). Finally, the permeability of genomes to introgression depends on the number and genomic distribution of factors that contribute to reproductive isolation; basically, less introgression is expected for genes that are tightly associated with loci contributing to reduced fitness (Rieseberg et al., 1999), while chromosomal blocks can introgress at a higher rate when they contribute to advantageous gene combinations with positive fitness consequences (Rieseberg et al., 1996b; Burke et al., 1998). The architecture of reproductive barriers between species thus plays a tremendous role in controlling the extent and distribution of introgression events. If a large number of evenly distributed factors contribute to hybrid sterility and/or inviability, then the main part of the genome should be protected from introgression by selection (Rieseberg et al., 1996a; Rieseberg et al., 1999). Conversely, if few reproductive barriers isolate species, then most of the genome is expected to be permeable to introgression (Kim and Rieseberg, 1999).

Recombination and selection against recombinants can also interact in a complex manner. On the one hand, enhanced recombination provides greater opportunities to move genes across species because it promotes introgression and simultaneously reduces linkage drag; on the other hand, it can disrupt co-adapted gene complexes, thereby causing hybrid sterility and breakdown that interfere negatively with introgression ( $\mathrm{Li}$ et al., 1997). In sunflower species, recurrent backcrossing to one or the other parent, which is likely when crop-wild hybrids occur at low frequency relative to their parents, proved to be an inefficient mechanism for breaking the parental linkage blocks compared to sib-mating (Rieseberg et al., 1996a). But populations resulting from sib-mating or selfing generally display higher levels of hybrid sterility and weakness than those derived by backcrossing (Rieseberg et al., 1996a). This balance is exemplified in Chèvre et al. (1997; 1998b) who observed 
a restoration of fertility, but no transgene introgression, in advanced BC generations of hybrids between transgenic oilseed rape and wild radish. Tomiuk et al. (2000) provided additional support to the effect of fitness differences on chromosome transmission and introgression in interspecific hybrids.

Hybridization can have several outcomes other than introgression that can lead to the persistence of crop genes in natural communities. For example, allopolyploidy is thought to be the most frequent solution to the problem of interspecific hybrid sterility and segregation. The presence of either unreduced gametes or endomitosis after fertilization leads to production of fertile allopolyploid F1 hybrids containing each of the parental genomes at the diploid stage (Bretagnolle and Thompson, 1995; Ramsey and Schemske, 1998). The production of such amphidiploid plants has been reported among crop-wild spontaneous hybrids (David et al., 2000; Rieger et al., 2001). Similarly, Johnsongrass (Sorgum halepense), which is one of the world's ten worst weeds, is considered to be an allotetraploid hybrid between $S$. bicolor and wild S. propinquum (Paterson et al., 1995). Hybrid fertility and stability can also be restored without any change in the ploidy level (homoploid stabilization), through the sorting of chromosomal rearrangements in later-generation hybrids (Rieseberg, 1997). This process can lead to the formation of a new stable and fertile population that is homozygous for a novel combination of rearrangements. Detailed reviews have recently addressed the mechanisms controlling polyploidization (Bretagnolle and Thompson, 1995; Ramsey and Schemske, 1998) and hybrid speciation (Rieseberg, 1997). They show that the opportunity for gene spread through hybrid speciation depends on the stability of the genomes, the pattern of mating between the hybrids and their parents, the fitness of the plants, and the availability of a new ecological niche that can be colonized by the hybrids.

\section{Fitness of wild-crop hybrids}

Most workers who attempted to determine the extent to which crop transgenes may persist in natural populations have concentrated on measuring $\mathrm{F} 1$ hybrid fitness. Fitness may be defined as the relative ability of an individual to survive and successfully reproduce in a given environment, with the most fit leaving the greatest number of offspring.

Fitness is a function of a wide range of components throughout life: seed dormancy, germinability, vegetative growth, viability and male/female fertility.
Identifying the most critical components is not straightforward and depends on the ecology of crop relatives. For instance, some models predict that seed bank dynamics and seedling establishment under competition are the strongest determinants of the persistence of weedy ephemeral populations that occupy disturbed areas (Linder and Schmitt, 1994; 1995). By contrast, most authors have only examined the vegetative and reproductive productivity of hybrids (Tab. 2), because these parameters seem more directly related to the number of offspring one individual can potentially leave. Integrating results obtained on different lifetime components is difficult; it is not clear, for instance, if the lifetime fitness of Brassica napus $\times$ B. rapa hybrids is influenced more by their competitive advantage during the seed-to-seedling stage of their life (Linder and Schmitt, 1995) or by their reduced pollen fertility (Hauser et al., 1998a). Trade-offs between different components of fitness (investment in survival vs. reproduction, male $v s$. female allocation) raise additional problems and may result in spuriously confounded effects (e.g. Hauser et al., 1998a).

Notwithstanding the difficulty of identifying and combining critical components of fitness, many studies that have examined fitness-related traits in wild-crop hybrids showed that early crop-weed hybrids are not uniformly less fit than their parental forms (Tab. 2). Wild-crop hybrids sometimes demonstrate enhanced vegetative vigor that contributes to their total fitness, since competitiveness is related to plant size (Langevin et al., 1990; Hauser at al., 1998a). These results challenge the classical view that wild-crop hybrids should be less fit than their wild parents due to the burden that crop traits would introduce into wild plants (De Wet and Harlan, 1975; Small, 1984; Ellstrand and Hoffman, 1990). Current understanding of the genetic basis of domestication traits suggest that few genomic regions are usually involved (White and Doebley, 1998; Poncet et al., 2000) and can thus be purged quite rapidly, with no long-term impact on crop-wild hybrid fitness.

Even when wild-crop hybrids are on average less fit than their parents, they are usually so variable that some of them often demonstrate equivalent fitness components to the parental forms (Eber et al., 1994; Baranger et al., 1995; Mikkelsen et al., 1996; Hauser et al., 1998ab). Crop-wild hybrids will almost certainly not be genetically uniform due to variation in wild (and perhaps crop) populations (Linder and Schmitt, 1994). As a portion of this variation is heritable (Hauser et al., 1998ab), different donor and recipient populations should be used to test ideally for the fitness of hybrids 
Review: Crop-to-wild gene flow, introgression and fitness effects of transgenes

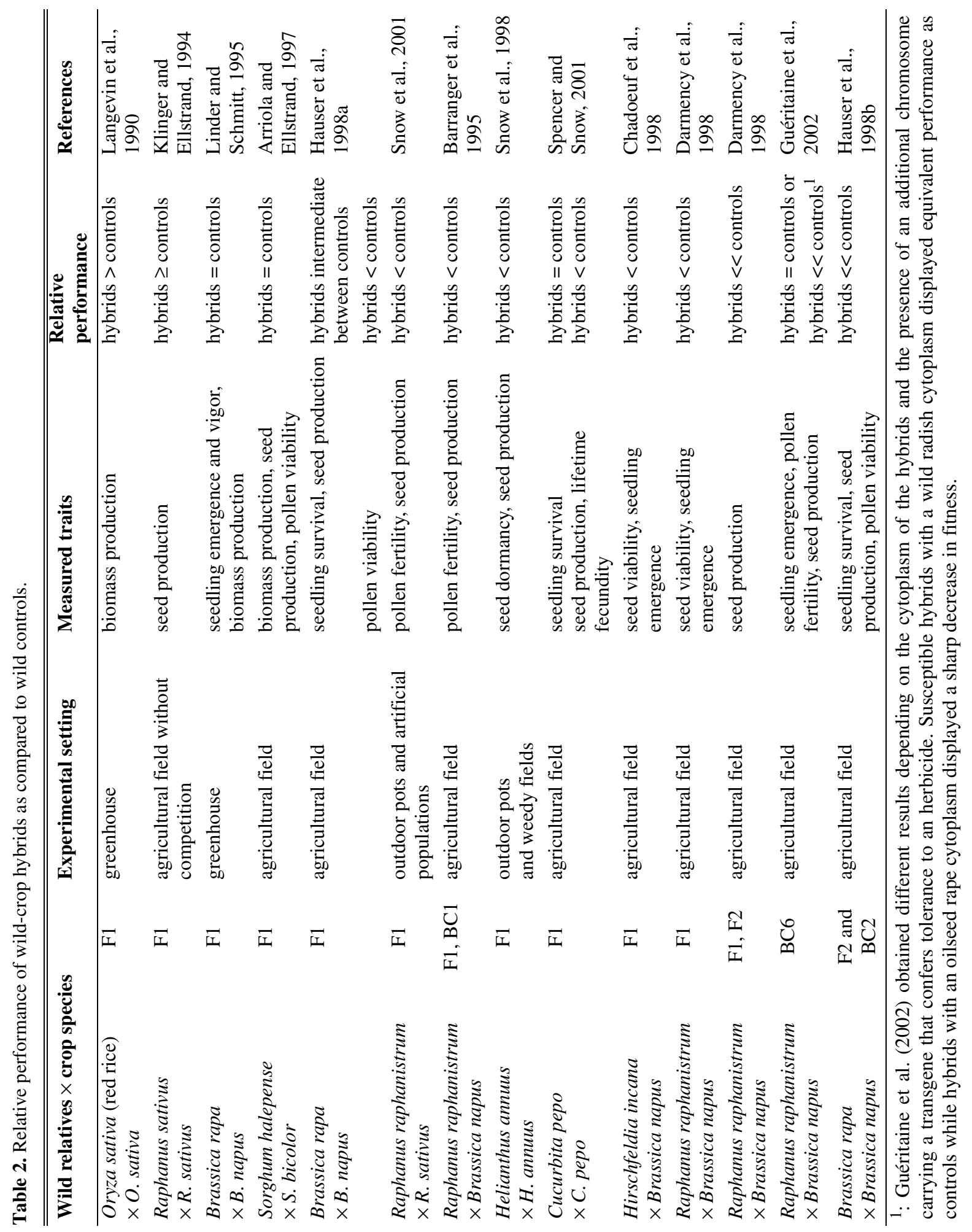


(Karieva et al., 1994; Hauser et al., 1998a; Spencer and Snow, 2001). Variation in fitness is also expected across the subsequent hybrid generations due to recombination and selection. Hauser et al. (1998ab) observed that the fitness of $B$. napus $\times$ B. rapa hybrids sharply decreased in the second generation of hybridisation, with F2 hybrids demonstrating the lowest survival and reproduction. Hybrid classes that are genotypically more similar to one of the parents generally display equivalent fitness components as compared to the parental form. This trend has been strikingly exemplified among $(B$. rapa $\times B$. napus) $\times B$. rapa hybrids (Mikkelsen et al., 1996); the highest pollen fertilities ( $>90 \%$ ) were observed among the hybrids that had a genomic structure close to $B$. rapa ( $2 n=20$ chromosomes).

According to Linder et al. (1998), estimates of early generations of crop-wild hybrid fitness may be of little predictive value for the assessment of transgene establishment unless hybrids are completely sterile. The long-term effects of a partial fitness barrier, i.e. when some hybrids survive but suffer from reduced fitness, are not clear. For instance, natural hybridizations between Helianthus annuus and $H$. petiolaris have resulted in at least three hybrid species (Rieseberg, 1997) despite very low fertility in the early generations of experimental hybridization. It must also be acknowledged that most studies have been performed under agricultural conditions, where water and soil nutrients were not limiting and inter-specific competition was low. The reproductive and vegetative performance documented in these experiments could have been different if relative hybrid fitness was evaluated outside of a cultivated field (Snow et al., 1998). Finally, very few studies have directly addressed the fitness of transgenic wild-crop hybrids (Linder and Schmitt, 1994; 1995; Snow et al., 1999; Spencer and Snow, 2001; Guéritaine et al., 2002). The fate of wild-crop hybrids and the spread of a transgene in natural communities will also depend on the nature of the genetically engineered traits.

\section{Fitness effects of transgene(s)}

Evaluating the spread and persistence of a transgene in free-living populations requires an understanding of whether possession of the transgene imposes a cost ("fitness penalty") on the plant in the absence of selection for this gene, whether it confers a selective advantage, or whether it is selectively neutral. Genes with different selective value are expected to pass through a species barrier at different rates even when the fitness of hybrids is rather depressed (Harrison, 1990). Clearly, these questions cannot be addressed globally.

First, the costs and benefits of transgenes depend largely on the phenotypic traits they confer to the wild plants. Some traits (production of pharmaceutical chemicals, modification of seed oil composition) are unlikely to be beneficial to free-living relatives; by contrast, genetically engineered herbicide tolerance, disease resistance and abiotic stresses tolerance are likely to enhance the fitness of plants carrying the transgene (Stewart et al., 1997; Snow et al., 1998). Second, the balance between costs and benefits is greatly affected by the nature and permanence of selective pressures acting on the transgene. For instance, resistance to a specific herbicide should only be beneficial to wild plants when and where the specific herbicide is frequently used, but this trait may be useless in most other natural communities. As exposure to biotic and abiotic stresses occur more continuously, genetically engineered tolerances to pest and abiotic stresses should enhance wild plant fitness in a wider range of habitats. Finally, the persistence of a transgene in wild populations not only depends on the balance between the costs and benefits this transgene impose on the wild plants, but also on the strength and frequency of gene flow. Population genetics theory predicts that strong and recurrent gene flow is sufficient to establish genes in populations where they contribute to slight fitness disadvantages (Haldane, 1930). The frequency of crop genes can thus be expected to increase in the wild populations if crop-to-wild gene flow is strong enough, irrespective of whether hybrids show increased or decreased relative fitness (Gliddon, 1994).

A complete treatment of the costs and benefits of transgenes is beyond the scope of this review, but several points can be briefly discussed. First, very few studies have attempted to evaluate the cost and benefit of transgene in crop-wild hybrids (e.g. Snow et al., 2001; Spencer and Snow, 2001; Guéritaine et al., 2002). Snow et al. (1999) demonstrated that there was no apparent fitness difference between transgenic and nontransgenic advanced hybrids of B. napus and B. rapa. Linder and Schmitt (1995) found little difference in the performance of oil-modified $B$. napus $\times B$. rapa seeds and seedlings as compared to non-modified controls. Some experiments have compared transgenic versus non-transgenic cultivated plants, but these studies cannot be used to predict the effects of transgenes on the invasiveness of weedy species. Although minimal cost must have been selected for in commercialized crops (Purrington and Bergelson, 1997), transgenes may 
Review: Crop-to-wild gene flow, introgression and fitness effects of transgenes

have different effects in another genetic background (pleiotropy and/or epistasis) or environment (Snow et al., 1999). Second, increased fitness of transgenic crops can increase the likelihood of introgression over evolutionary time by making it easier for crop individuals to persist in natural communities. Stewart et al. (1997) observed that $B t$-transgenic B. napus had a better overwinter survivorship when selection pressures are exerted by insects. Conversely, Crawley et al. (1993) found no evidence for enhanced weediness in transgenic B. napus expressing herbicide tolerance. Finally, costs of resistance are expected to be more evident in a stressful environment (Reboud and Till-Bottraud, 1991; Bergelson, 1994). It has been suggested that when resources are abundant enough, excess resources can be channelled into resistance expression without significant consequences on fitness.

\section{CONCLUSION AND PERSPECTIVES}

To date, most studies have taken a short-term view of how transgenes may disperse and establish, and very few studies have assessed the extent of crop-to-wild hybridization in normal agronomical conditions (Wilson and Manhart, 1993; Whitton et al., 1997; Chèvre et al., 2000; Wilkinson et al., 2000; Rieger et al., 2001). In light of both theoretical and empirical data, our review suggests that gene dispersion will be very difficult to preclude totally. The most intuitive predictors of transgene escape (e.g. breeding system, relative ploidy level of both crop and weeds) are not sufficient on their own to correctly assess the associated risk. Crop-to-weed gene flow appears to be highly idiosyncratic and may be considered as crop-specific, and to some extent, varietyspecific, site-specific or even season-specific (Raybould and Gray, 1993). Early crop-wild hybrid fitness and the intrinsic costs and benefits of transgene are important parameters that must be taken into account when considering gene establishment (Fig. 1), but they are not sufficient to draw definite conclusions about the associated risks. Natural selection will act on transgenic organisms or hybrids as it does on all others. Selection after the release of the transgenic plant will tend to increase fitness, not decrease it, by reducing the cost directly or indirectly associated with the novel traits (Tiedje et al., 1989). An important prerequisite is thus to verify that some genotypes will survive and reproduce at each generation, and thereby provide many opportunities for natural selection to operate.

Studies dedicated to assessing transgene escape and establishment have provided a wealth of useful information and challenged the previous paradigms, such as the assumptions that crop-to-wild hybridization will never occur or that crop-wild hybrids will be systematically unfit, sterile or not viable. The future directions for research should question the long-term establishment and effects of transgene on natural communities, especially with regard to:

- The ecology and population dynamics of weeds and feral crops. The size, demography, and structure of weed populations can be critical determinants of the spread of transgenes, but are still difficult to apprehend. A proper evaluation of crop seed dispersal, establishment and persistence in wild communities is also required to understand the role of escapees in crop-to-wild gene flow.

- A more accurate understanding of the way the different factors shape the distribution of introgression and interact with one another. This information is important to predict the risks for transgene escape into wild communities and to identify "safer" insertion sites for transgenes (i.e. where the chance for subsequent introgression is reduced).

- The efficiency and consequences of the different strategies proposed to reduce crop-to-wild gene flow. Different confinement strategies have been proposed, but only a few have been tested. For instance, Morris et al. (1994) have shown that narrow barren zones are inefficient, and that trap beds increase gene escape when the source and recipient populations are growing nearby (Manasse, 1992). Only wider zones of trap crop captured more escaping pollen. Further studies are now required to test the efficiency and consequences of complete selffertilizing varieties for partially autogamous crops (e.g. oilseed rape) or male-sterile lines for species used for their vegetative products (e.g. poplar or cauliflower). Similarly, genetic strategies that aim to reduce seed loss at harvesting and dormancy or to cope with herbicide tolerant volunteers are useful to reduce the impact of temporal transgene dispersal and must thus be investigated.

- The development of genetic studies at the population level - population genetic theory has challenged the classical belief that wild-crop hybrids must be as fit or more fit than wild plants in order for the engineered crop genes to persist and establish in the wild (Ellstrand and Hoffman, 1990; Klinger and Ellstrand, 1994; Scott and Wilkinson, 1998). But as Gliddon (1994) rightly emphasized, "although population genetic theory allows certain approximate statements to be made concerning the fate of genes introgressed from transgenic crops, there has been insufficient work on more ecologically realistic 
population structure to allow for reasonable inferences to be made concerning rates of spread of genes". Thus, more studies that integrate ecological and genetic information are needed to allow a more accurate prediction of the fate of introgressed genes. Moreover, if hybridization may be a stimulus for the evolution of invasiveness (Ellstrand and Schierenbelk, 2000), the different factors that are responsible for the shift between the different steps of invasiveness must be understood in order to predict the risks due to crop-to-wild hybrids. Ecological and evolutionary studies are also needed to predict the evolutionary response of free-living populations (crop relatives, pest) to the genetically modified organisms.

Finally, as already stressed by Ellstrand et al. (1999), the question of crop-to-wild gene flow should not be restricted only to the case of transgenic organisms. Considering the potentialities and extent of crop-to-wild gene flow is also relevant for genetic resource conservation. Until now, few studies have addressed this question (Bartsch et al., 1999; Jenczewski et al., 1999).

\section{ACKNOWLEDGEMENTS}

Many thanks are due to T. Bataillon, J. David and F. Eber for valuable discussions on previous versions of this manuscript. We also want to thank A.A. Snow for her fruitful comments on the submitted manuscript.

Received October 2, 2001; accepted October 8, 2002.

\section{REFERENCES}

Arias DM, Rieseberg LH (1994) Gene flow between cultivated and wild sunflowers. Theor. Appl. Genet. 89: 655-660

Arnold ML (1997) Natural hybridization and evolution. Oxford University Press, Oxford

Arriola PE, Ellstrand NC (1996) Crop-to-weed gene flow in the genus Sorghum (Poaceae): spontaneous interspecific hybridization between johnsongrass, Sorghum halepense, and crop sorghum, S. bicolor. Am. J. Bot. 83: 1153-1160

Arriola PE, Ellstrand NC (1997) Fitness of interspecific hybrids in the genus Sorghum: persistence of crop genes in wild populations. Ecol. Appl. 7: 512-518

Baranger A, Chèvre AM, Eber F, Renard M (1995) Effect of oilseed rape genotype on the spontaneous hybridization rate with a weedy species: an assessment of transgene dispersal. Theor. Appl. Genet. 91: 956-963

Bartsch D, Lehnen M, Clegg J, Pohl-Orf M, Schuphan I, Ellstrand NC (1999) Impact of gene flow from cultivated beet on genetic diversity of wild sea beet populations. Mol. Ecol. 8: 1733-1741
Bergelson J (1994) Changes in fecundity do not predict invasiveness: a model study of transgenic plants. Ecology 75: 249-252

Bing DJ, Downey RK, Rakow GFM (1996) Hybridizations among Brassica napus, B. rapa and B. juncea and their weedy relatives $B$. nigra and Sinapis arvensis under open pollination conditions in the fields. Plant Breed. 115: 470-473

Boudry P, Mörchen M, Saumitou-Laprade P, Vernet P, Van Dijk H (1993) The origin and evolution of weed beets: consequences for the breeding and release of herbicide-resistant transgenic sugar beets. Theor. Appl. Genet. 87: 471-478

Bretagnolle F, Thompson JD (1995) Gametes with the somatic chromosome number: mechanisms of their formation and role in the evolution of autopolyploid plants. New Phytol. 129: $1-22$

Burke JM, Voss TJ, Arnold ML (1998) Genetic interactions and natural selection in Louisiana iris hybrids. Evolution 52: 1304-1310

Chadoeuf R, Darmency H, Maillet J, Renard M (1998) Survival of buried seeds of interspecific hybrids between oilseed rape, hoary mustard and wild radish. Field Crop Res. 58: 197-204

Chèvre AM, Eber F, Baranger A, Renard M (1997) Gene flow from transgenic crops. Nature 389: 924

Chèvre AM, Eber F, Baranger A, Boucherie R, Broucqsault LM, Bouchet Y, Renard M (1998a) Risks assessment on crucifer species. Acta Hort. 459: 219-224

Chèvre AM, Eber F, Baranger A, Hureau G, Barret P, Picault H, Renard M (1998b) Characterisation of backcross generations obtained under field conditions from oilseed rape-wild radish F1 interspecific hybrids: an assessment of transgene dispersal. Theor. Appl. Genet. 97: 80-98

Chèvre AM, Eber F, Darmency H, Fleury A, Picault H, Letanneur JC, Renard M (2000) Assessment of interspecific hybridization between transgenic oilseed rape and wild radish under normal agronomic conditions. Theor. Appl. Genet. 100: 1233-1239

Conner AJ, Dale PJ (1996) Reconsideration of pollen dispersal data from field trials of transgenic potatoes. Theor. Appl. Genet. 92: 505-508

Crawley MJ, Brown SL (1995) Seed limitation and the dynamics of feral oilseed rape on the M25 motorway. Proc. Roy. Soc. Lond. 259: 49-54

Crawley MJ, Hails RS, Rees M, Kohn D, Buxton J (1993) Ecology of transgenic oilseed rape in natural habitats. Nature 363: 620-623

Darmency H, Lefol E, Fleury A (1998) Spontaneous hybridizations between oilseed rape and wild radish. Mol. Ecol. 7: 1467-1473

David JL, Bousseau D, Dussautoir J-C (2000) Étude sur les possibilités d'hybridation entre les blés cultivés et quelques espèces apparentées (Aegilops spp.) en France. $\mathrm{XI}^{\mathrm{e}}$ colloque international sur la biologie des mauvaises herbes. Dijon, France, pp 6-8 
Review: Crop-to-wild gene flow, introgression and fitness effects of transgenes

De Vries FT, van der Meijden R, Brandenburg WA (1992) Botanical files: a study of the real chances for spontaneous gene flow from cultivated plants to the wild flora of the Netherlands. Gorteria suppl1, Rijksherbarium / Hortus Botanicus, Leiden

De Wet JMJ, Harlan JR (1975) Weeds and domesticates: Evolution in the man-made habitat. Econ. Bot. 29: 99-107

Delourme R, Foisset N, Horvais R, Barret P, Champagne G, Cheung WY, Landry BS, Renard M (1998) Characterisation of the radish introgression carrying the Rfo restorer gene for the Ogu-INRA cytoplasmic male sterility in rapeseed (Brassica napus L.). Theor. Appl. Genet. 97: 129-134

Doebley JF (1990) Molecular evidence for gene flow among Zea species. Bioscience 40: 443-448

Dvorak J (1972) Genetic variability in Aegilops speltoides affecting homoelogous pairing in wheat. Can. J. Genet. Cytol. 14: $371-380$

Eber F, Chèvre AM, Baranger A, Vallée $\mathbf{P}$, Tanguy $\mathbf{X}$, Renard M (1994) Spontaneous hybridization between a male-sterile oilseed rape and two weeds. Theor. Appl. Genet. 88: $362-368$

Eber F, Boucherie R, Broucqsault LM, Bouchet Y, Chèvre AM (1998) Spontaneous hybridization between vegetable crops and weeds 1 . Garden radish (Raphanus sativus L.) and wild mustard (Sinapis arvensis L.). Agronomie 18: 489-497

Ellstrand NC (1992) Gene flow by pollen; implications for plant conservation genetics. Oikos 63: 77-86

Ellstrand NC (2001) When transgenes wander, should we worry? Plant Physiol. 125: 1543-1545

Ellstrand NC, Hoffman CA (1990) Hybridization as an avenue of escape for engineered genes. Bioscience 40: $438-442$

Ellstrand NC, Schierenbelk KA (2000) Hybridization: a stimulus for the evolution of invasiveness in plants? Proc. Natl. Acad. Sci. USA 97: 7043-7050

Ellstrand NC, Devlin D, Marshall DL (1989) Gene flow by pollen into small populations: Data from experimental and natural stands of wild radish. Proc. Natl. Acad. Sci. USA 86: 9044-9047

Ellstrand NC, Prentice HC, Hancock JF (1999) Gene flow and introgression from domesticated plants into their wild relatives. Ann. Rev. Ecol. Syst. 30: 539-563

Evans MMS, Kermicle JL (2001) Teosinte crossing barrierl, a locus governing hybridisation of teosinte with maize. Theor. Appl. Genet. 103: 259-265

Frankel OM, Brown AHD, Burdon JJ (1995) The conservation of plant biodiversity. Cambridge University Press, Cambridge, $299 \mathrm{p}$

Gallais A, Bannerot H (1992) Amélioration des espèces végétales cultivées. Objectifs et critères de sélection. INRA Éditions, Paris

Gauthier FM, McGinnis RC (1968) The meiotic behaviour of a nulli-haploid plant in Avena sativa. Can. J. Genet. Cytol. 10: 186-189
Giddings GD, Sackville Hamilton NR, Hayward MD (1997a) The release of genetically modified grasses. Part 1: pollen dispersal to traps in Lolium perenne. Theor. Appl. Genet. 94: 1000-1006

Giddings GD, Sackville Hamilton NR, Hayward MD (1997b) The release of genetically modified grasses. Part 2: the influence of wind direction on pollen dispersal. Theor. Appl. Genet. 94: 1007-1014

Gliddon C (1994) The impact of hybrids between genetically modified crop plants and their related species: biological models and theoretical perspectives. Mol. Ecol. 3: 41-44

Guéritaine G, Sester M, Eber F, Chèvre AM, Darmency H (2002) Fitness components of progeny of hybrids between transgenic oilseed rape (Brassica napus) and wild radish (Raphanus raphanistrum). Mol. Ecol. 11: 1419-1426

Hails RS, Rees M, Kohn DD, Crawley MJ (1997) Burial and seed survival in Brassica napus subsp. oleifera and Sinapis arvensis including a comparison of transgenic and non-transgenic lines of the crop. Proc. Roy. Soc. Lond. 264: $1-7$

Haldane JBS (1930) A mathematical theory of natural and artificial selection. Part IV: Isolation. Proc. Cambridge Philos. Soc. 26: 20-30

Harlan JR (1992) Crops and Man. American society of Agronomy, Madison

Harrison RG (1990) Hybrid zones: windows on evolutionary process. Oxford surveys in Evolutionary Biology, Oxford University Press, Oxford, pp 69-128

Hauser TP, Jorgensen RB, Ostergard H (1997) Preferential exclusion of hybrids in mixed pollinations between oilseed rape (Brassica napus) and weedy B. campestris. Am. J. Bot. 84: 756-762

Hauser TP, Shaw RG, Ostergard H (1998a) Fitness of F1 hybrids between weedy Brassica rapa and oilseed rape (B. napus). Heredity 81: 429-435

Hauser TP, Jorgensen RB, Ostergard H (1998b) Fitness of backcross and F2 hybrids between weedy Brassica rapa and oilseed rape (B. napus). Heredity 81: 436-443

Hodges SA, Burke JM, Arnold ML (1996) Natural formation of iris hybrids: experimental evidence on the establishment of hybrid zones. Evolution 50: 2504-2509

Jauhar PP (1993) Cytogenetics of the Festuca-Lolium complex. Relevance to plant breeding. Monographs on Theoretical and Applied Genetics 18, Springer-Verlag, Heidelberg

Jenczewski E, Prosperi JM, Ronfort J (1999) Evidence for gene flow between wild and cultivated Medicago sativa (Leguminosae) based on allozyme and quantitative traits. Am. J. Bot. 86: 677-687

Johnston SA, den Nijs TPM, Peloquin SJ, Hanneman Jr RE (1980) The significance of genic balance to endosperm development in interspecific crosses. Theor. Appl. Genet. 57: 5-9

Jorgensen RB, Andersen B (1994) Spontaneous hybridization between oilseed rape (Brassica napus) and weedy 
B. campestris (Brassicaceae): a risk of growing genetically modified oilseed rape. Am. J. Bot. 81: 1620-1626

Kareiva PM, Morris W, Jacobi CM (1994) Studying and managing the risk of cross-fertilization between transgenic crops and their wild relatives. Mol. Ecol. 3: 15-21

Kerlan MC, Chèvre AM, Eber F, Baranger A, Renard M (1992) Risk assessment of outcrossing of transgenic rapeseed to related species: I. Interspecific hybrid production under optimal conditions with emphasis on pollination and fertilization. Euphytica 62: 145-153

Kim SC, Rieseberg LH (1999) Genetic architecture of species differences in annual sunflowers: Implications for adaptive trait introgression. Genetics 153: 965-977

Kirkpatrick KJ, Wilson HD (1988) Interspecific gene flow in Curcubita: C. texana vs. C. pepo. Am. J. Bot. 75: 519-527

Klinger T, Ellstrand NC (1994) Engineered genes in wild populations: fitness of weed-crop hybrids of Raphanus sativus. Ecol. Appl. 41: 117-120

Klinger T, Arriola PE, Ellstrand NC (1992) Crop-weed hybridization in radish (Raphanus sativus): effects of distance and population size. Am. J. Bot. 79: 1431-1435

Langevin SA, Clay K, Grace JB (1990) The incidence and effects of hybridization between cultivated rice and its related weed red rice (Oryza sativa L.). Evolution 44: 1000-1008

Lavigne C, Godelle B, Reboud X, Gouyon PH (1998) A method to determine the mean pollen dispersal of individual plants growing within a large pollen source. Theor. Appl. Genet. 93: 1319-1326

Lewis J (1973) Longevity of crop and weed seeds: survival after 20 years in soil. Weed Res. 13: 179-191

Li Z, Pinson SRM, Paterson AH, Park WD, Stansel JW (1997) Genetics of hybrid sterility and hybrid breakdown in an intersubspecific rice (Oryza sativa L.) population. Genetics 145: 1139-1148

Linder CR, Schmitt J (1994) Assessing the risks of transgene escape through time and crop-wild hybrid persistence. Mol. Ecol. 3: 23-30

Linder CR, Schmitt J (1995) Potential persistence of escaped transgenes: performance of transgenic oil-modified Brassica seeds and seedlings. Ecol. Appl. 5: 1056-1068

Linder CR, Taha I, Seiler GJ, Snow AA, Rieseberg LH (1998) Long-term introgression of crop genes into wild sunflower populations. Theor. Appl. Genet. 96: 339-347

Luby JJ, McNicol RJ (1995) Gene flow from cultivated to wild raspberries in Scotland: developing a basis for risk assessment for testing and deployment to transgenic cultivars. Theor. Appl. Genet. 90: 1133-1137

Lukaszewski AJ (1995) Physical distribution of translocation breakpoints in homeologous recombinants induced by the absence of the $P h 1$ gene in wheat and triticale. Theor. Appl. Genet. 90: 714-719

Manasse RS (1992) Ecological risks of transgenic plants: effects of spatial dispersion on gene flow. Ecol. Appl. 2: $431-438$
McPartlan HC, Dale PJ (1994) An assessment of gene transfer by pollen from field-grown transgenic potatoes to nontransgenic potatoes and related species. Transgenic Res. 3: 216-225

Metz PL, Jacobsen E, Nap JP, Pereira A, Stiekema WJ (1997) The impact on biosafety of the phosphinothricintolerance transgene in interspecific $B$. rapa $\times B$. napus hybrids and their successive backcrosses. Theor. Appl. Genet. 95: 442-450

Mikkelsen TR, Andersen B, Jorgensen RB (1996) The risk of crop transgene spread. Nature 380: 31

Moore G, Aragon-Alcaide L, Roberts M, Reader S, Miller T, Foote T (1997) Are rice chromosomes components of a holocentric chromosome ancestor? Plant Mol. Biol. 35: $17-23$

Morris WF, Karieva PM, Raymer PL (1994) Do barren zones and pollen traps reduce gene escape from transgenic crops? Ecol. Appl. 4: 157-165

Panetsos CA, Baker H (1967) The origin of variation in "wild" Raphanus sativus in California. Genetica 38: 243-274

Pascher K, Gollmann G (1997) Ecological risk assessment of transgenic plant releases: an austrian perspective. Biodiv. Conser. 8: 1139-1158

Paterson AH, Schertz KF, Lin Y, Lui S, Chang Y (1995) The weediness of wild plants: molecular analysis of genes influencing dispersal and persistence of Johnsongrass; Sorghum halepense (L.) Pers. Proc. Natl. Acad. Sci. USA 92: 1686-1691

Pessel FD, Lecomte J, Emeriau V, Krouti M, Messean A, Gouyon PH (2001) Persistence of oilseed rape (Brassica napus L.) outside of cultivated fields. Theor. Appl. Genet. 102: 841-846

Poncet V, Lamy F, Devos KM, Gale MD, Sarr A, Robert T (2000) Genetic control of domestication traits in pearl millet (Pennisetum glaucum L., Poaceae). Theor. Appl. Genet. 100: 147-159

Poppy GM (2000) GM crops: environmental risks and nontarget effects. Trends Plant Sci. 5: 4-6

Price JS, Hobson RN, Neale MA, Bruce DM (1996) Seed losses in commercial harvesting of oilseed rape. J. Agric. Engineer. Res. 65: 183-191

Purrington CB, Bergelson J (1997) Fitness consequences of genetically engineered herbicide and antibiotic resistance in Arabidopsis thaliana. Genetics 145: 807-814

Ramsey J, Schemske DW (1998) Pathways, mechanisms, and rates of polyploid formation in flowering plants. Ann. Rev. Ecol. Syst. 29: 467-501

Raybould AF, Gray AJ (1993) Genetically modified crops and hybridization with wild relatives: a UK perspective. J. Appl. Ecol. 30: 199-219

Reboud X, Till-Bottraud I (1991) The cost of herbicide resistance measured by a competition experiment. Theor. Appl. Genet. 82: 690-696

Regal PJ (1994) Scientific principles for ecologically based risk assessment of transgenic organisms. Mol. Ecol. 3: 5-13 
Review: Crop-to-wild gene flow, introgression and fitness effects of transgenes

Renno JF, Winkel T (1996) Phenology and reproductive effort of cultivated and wild forms of Pennisetum glaucum under experimental conditions in the Sahel: implications for the maintenance of polymorphism in the species. Can. J. Bot. 74: 959-964

Rieger MA, Potter TD, Preston C, Powles SB (2001) Hybridisation between Brassica napus L. and Raphanus raphanistrum L. under agronomic field conditions. Theor. Appl. Genet. 103: 555-560

Rieseberg LH (1997) Hybrid origins of plant species. Ann. Rev. Ecol. Syst. 28: 359-389

Rieseberg LH, Carney SE (1998) Plant hybridization. New Phytol. 140: 599-624

Rieseberg LH, Wendel JF (1993) Introgression and its consequences in plants. In Harrison RG, ed, Hybrid Zones and the Evolutionary Process. Oxford University Press, Oxford, pp 70-109

Rieseberg LH, Desrochers AM, Youn SJ (1995) Interspecific pollen competition as a reproductive barrier between sympatric species of Helianthus (Asteraceae). Am. J. Bot. 82: 515-519

Rieseberg LH, Arias DM, Ungerer MC, Linder CR, Sinervo B (1996a) The effects of mating design on introgression between chromosomally divergent sunflower species. Theor. Appl. Genet. 93: 633-644

Rieseberg LH, Linder CR, Seiler GJ, Ungerer MC, Arias DM (1996b) Role of gene interactions in hybrid speciation: Evidence from ancient and experimental hybrids. Science 272: $741-745$

Rieseberg LH, Whitton J, Gardner K (1999) Hybrid zone and the genetic architecture of a barrier to gene flow between two sunflower species. Genetics 152: 713-727

Riley R (1963) The genetic regulation of meiotic behaviour in wheat and its relatives. Hereditas suppl. 2: 395-408

Robert T, Lespinasse R, Pernès J, Sarr A (1991) Gametophytic competition as influencing gene flow between wild and cultivated forms of pearl millet (Pennisetum typhoides). Genome 34: 195-200

Rognli OA, Nilsson NO, Nurminiemi M (2000) Effects of distance and pollen competition on gene flow in the windpollinated grass Festuca pratensis Huds. Heredity 85: 550-560

Sacks EJ, Gerhardt LM, Graham EB, Jacobs J, Thorrup TA, St Clair DA (1997) Variation among 41 genotypes of tomato (Lycopersicum esculentum Mill) for crossability to L. peruvianum (L.) Mill. Ann. Bot. 80: 469-477

Santoni S, Bervillé A (1992) Evidences for gene exchanges between sugar beet (Beta vulgaris L.) and wild beets: consequence for transgenic sugar beets. Plant Mol. Biol. 20: 575-580

Scheffler JA, Parkinson R, Dale PJ (1993) Frequency and distance of pollen dispersal from transgenic oilseed rape (Brassica napus). Transgenic Res. 2: 356-364

Scott SE, Wilkinson MJ (1998) Transgene risk is low. Nature 393: 320
Seefeldt SS, Zemettra RS, Young FL, Jones SS (1998) Production of herbicide-resistant jointed goatgrass (Aegilops cylindrica) $\times$ wheat (Triticum aestivum) hybrids in the field by natural hybridization. Weed Sci. 46: 632-634

Simmonds NW (1995) Evolution of crop plants. Longman Scientific and Technical, New York

Skogsmyr I (1994) Gene dispersal from transgenic potatoes to co-specifics: a field trial. Theor. Appl. Genet. 88: 770-774

Small E (1984) Hybridization in the domesticated weed-wild complex. In Grant WF, ed, Plant Biosystematics. Academic Press, Toronto, pp 195-210

Snow AA, Morán Palma PM (1997) Commercialization of transgenic plants: potential ecological risks. Bioscience 47: 86-96

Snow AA, Morán Palma P, Rieseberg LH, Wszelaki A, Seiler GJ (1998) Fecundity, phenology, and seed dormancy of F1 wild-crop hybrids in sunflower (Helianthus annuus, Asteraceae). Am. J. Bot. 85: 794-801

Snow AA, Andersen B, Jorgensen RB (1999) Costs of transgenic herbicide resistance introgressed from Brassica napus into weedy B. rapa. Mol. Ecol. 8: 605-615

Snow AA, Uthus KL, Culley TM (2001) Fitness of hybrids between weedy and cultivated radish: implications for weed evolution. Ecol. Appl. 11: 934-943

Spencer LJ, Snow AA (2001) Fecundity of transgenic wildcrop hybrids of Curcubita pepo (Cucurbitaceae): implications for crop-to-wild gene flow. Heredity 86: 694-702

St. Amand PC, Skenner DZ, Peaden RN (2000) Risk of alfalfa transgene dissemination and scale-dependent effects. Theor. Appl. Genet. 101: 107-114

Stewart CN, All JNJ, Raymer PL, Ramachandran S (1997) Increased fitness of transgenic insecticidal rapeseed under insect selection pressure. Mol. Ecol. 6: 773-779

Taylor IB, Evans GM (1977) The genotypic control of homoeologous chromosome associations in Lolium temulentum $\times$ Lolium perenne interspecific hybrids. Chromosoma 62: 57-67

Tiedje JM, Colwell RK, Grossman YL, Hodson RE, Lenski RE, Mack RN, Regal PJ (1989) The planned introduction of genetically engineered organisms: ecological considerations and recommendations. Ecology 70: 298-315

Till-Bottraud I, Reboud X, Brabant P, Lefranc M, Rherissi B, Vedel F, Darmency H (1992) Outcrossing and hybridization in wild and cultivated foxtail millets: consequences for the release of transgenic plants. Theor. Appl. Genet. 83: 940-946

Tomiuk J, Hauser TP, Bagger-Jorgensen R (2000) A- or Cchromosomes, does it matter for the transfer of transgenes from Brassica napus? Theor. Appl. Genet. 100: 750-754

Truco MJ, Hu J, Sadowski J, Quiros C (1996) Inter- and intra-genomic homology of the Brassica genomes: implications for their origin and evolution. Theor. Appl. Genet. 93: 1225-1233

Tynan JL, Williams MK, Conner AJ (1990) Low frequency of pollen dispersal from a field trial of transgenic potatoes. J. Genet. Breed. 44: 303-306 
van Raamsdonk LWD (1995) The cytological and genetical mechanism of plant domestication exemplified by four crop models. Bot. Rev. 61: 367-399

White S, Doebley J (1998) Of genes and genomes and the origin of maize. Trends Genet. 14: 327-332

Whitton J, Wolf DE, Arias DM, Snow AA, Rieseberg LH (1997) The persistence of cultivar alleles in wild populations of sunflowers five generations after hybridisation. Theor. Appl. Genet. 95: 33-40

Wilkinson MJ, Davenport IJ, Charters YM, Jones AE, Allainguillaume J, Butler HT, Mason DC, Raybould AF
(2000) A direct regional scale estimate of transgene movement from genetically modified oilseed rape to its wild progenitors. Mol. Ecol. 9: 983-991

Wilson HD (1990) Gene flow in squash species. Bioscience 40: 449-455

Wilson H, Manhart J (1993) Crop/Weed gene flow: Chenopodium quinoa Willd and C. berlandieri Moq. Theor. Appl. Genet. 86: 642-648

Zemettra RS, Hansen J, Mallory-Smith CA (1998) Potential for gene transfer between wheat (Triticum aestivum) and jointed goatgrass (Aegilops cylindrica). Weed Sci. 46: 313-317

To access this journal online: www.edpsciences.org 